\title{
Cutaneous Squamous Cell Carcinoma of the Head and Neck
}

National Cancer Institute

\section{Source}

National Cancer Institute. Cutaneous Squamous Cell Carcinoma of the Head and Neck. NCI Thesaurus. Code C133252.

A squamous cell carcinoma that arises from the skin of the head and neck. 